\title{
Race in South Africa: A hidden transcript turned public? THE PROBLEM OF IDENTIFYING WITH ESTHER / MORDECAI OR HAMAN IN THE BOOK OF ESTHER ${ }^{1}$
}

\author{
Gerrie Snyman \\ Department of Old Testament \\ University of South Africa
}

\begin{abstract}
Based on two grass roots readings of Esther 9 in terms of violence and power, the author discusses the issue of race, identity and power. His entry point is based on the notions of public and hidden transcripts as developed by James Scott's book Domination and the arts of resistance. Hidden transcripts (1990). The article explains the current South African public transcript in terms of racialisation, reconciliation and the problematisation of whiteness. It then looks into aspects of identity in the Book of Esther, exploring the problem of reading the Bible in terms of race. It concludes that because the negative use of race constructs the public transcript at the moment, its construction can also be observed in the current Bible reading process at grass roots level. It is a transcript of superiority over those whose existence is moulded along Western cultural lines, the perpetrators of the former regime.
\end{abstract}

\section{The question}

The question posed in the title of this paper originated from two readings of Esther 9 that I encountered in a course facilitating the move from the biblical text to the construction of a sermon. Since 1994 (a decisive moment in South African history), students from a specific political, cultural and socio-economic sector have experienced an associative identification with the characters of Esther and Mordecai and a disassociative identification with Haman and his woes. In a society highly polarised in terms of race, gender, culture and economy in the early 90's, it meant that Esther and Mordecai were identified with the struggle for liberation and the oppressors with Haman. In these two readings a positive identification with Esther and a negative identification with Haman boil down to racial lines of interpretation.

I was deeply disturbed by these readings, as can be seen in the way these stories have become a central theme in my critical thinking. ${ }^{2}$ I was confronted by a reading from the formerly oppressed group which had racial concerns, whereas the liberation struggle has

1. This article is an edited version of a paper read at the SBL at Denver, USA in November 2001. I should like to express my gratitude to the NRF and the RC at Unisa, which made that visit possible.

2. These two readings have become, during the past few years, the framework for my own critical thinking. I first referred to these readings in 1997 at the NTSSA (cf. Snyman 1999) where I tried to look at them from the point of view of critical versus lay reading. In 1998 I tried to view the readings from the perspective of fundamentalism, civil religion and rhetorical identification at a conference on religion and rhetoric in Florence (cf. Snyman 2002a). Yet again, in September 2001, these two readings, together with another one from Zimbabwe, helped me to problematise the kind of reading in my own church community (at a workshop on the role of women in church and society under the auspices of the Faculty of Theology of the PU for CHE), where discriminatory practices against women are the order of the day and theologically justified (cf. Snyman 2002b). 
been presented as a fight that will overcome racism. The formerly oppressed were not supposed to think in terms of racial groupings. Moreover, there is a general feeling that the issue of racism is simply a Western scourge.

If I were to brush off these two readings as irrationalism or "closeted racism" amongst black individuals, this would mean that I, in effect, would sanitise and relativise the colonial project in the same way that some Neo-conservative historians tried to sanitise German history in the 1980's. More likely, the focus on race is still a residue of the colonial project that started, for South Africa, in the $17^{\text {th }}$ century. The importance of race simply became deeply ingrained, and it is not going to be obliterated within days or even years. It had a profound influence on every South African's existence, even on our thought structures, no matter where one stands in the continuum of the oppressed and the oppressor. Race has been inscribed into our public transcript by colonialism.

Here are the two readings. The one is from a rural area in the Northern Province and the other from an urban township in the Witwatersrand. The students read the Book of Esther in terms of a narrative approach, with an eye to preparing a religious text, such as a sermon or a meditation. The focus fell on narrative perspective (wisdom) and characterisation. Their attention was drawn to Esther's ambivalent position in terms of a world which was both ordered and chaotic. The problem they had to address in this sermon was the problem of violence and power in Esther 9, where she asked for a second day of killings. Admittedly, this kind of question is moralistic (cf. Snyman 2002a) in the sense that the students had to decide in what measure they were able to identify with the characters of Esther, Mordecai or Haman in terms of Hans-Robert Jauß' (1989) modes of identification.

\section{(a) A rural reception in the Northern province}

The audience for whom this student constructed his meditation consisted of adults, of whom the majority had only a primary education. The student himself was of indigenous African origins and worked in the community of his birth in the Northern Province. His audience did not comprise skilled workers. Most merely did piece jobs, were unemployed or pensioners. A few possessed a tertiary education and worked as politicians, teachers and in some other professions. They were all bounded by a particular view of Scripture that put a high premium on authority, especially scriptural authority.

In his meditation the student used Esther 9 to justify the violence of the struggle for liberation. He wrote at a time when the Truth and Reconciliation Commission (TRC) had opened apartheid's can of worms. His aim was to compare the liberation struggle with the killing of the Persians, in order to legitimise the use of violence and Christian participation in it. He spoke favourably of religious leaders such as the late Trevor Huddleston, Desmond Tutu and Beyers Naudé, all anti-apartheid stalwarts revered as near saints! With these strong figures representing the moral fibre of the struggle, he questioned the morality of petrol bombs, necklacing and the burning of buildings during the struggle.

He did not want to outrightly condemn the kind of violence when people were innocently struck. He regarded the ensuing violence as a defence mechanism, a case of killing one's adversaries before they kill oneself. This is the principle he saw operating in the Book of Esther. Haman and the Persians manipulated the king to issue a decree to have the Jews killed. Esther and Mordecai had no choice but to defend their people against the envisaged massacre. There was no other way out. The situation was provoked by the Persians.

Those good reasons for the violent actions of Esther and Mordecai became equally reasons for employing violence during the struggle. Such violence was perceived as 
counter-violence against the state's violence of tear-gassing, sjambokking, detention without rial, and torturing opponents. The apartheid system was likened to the actions of the Persians and the liberation from apartheid was likened to the Jews' fight against the Persians.

(b) An urban reception in the context of extreme poverty

A year later, another African student from a very poor township in Randfontein provided an unrefined reception of Esther 9 by explicitly identifying the black people of South Africa with the Jews and the white South Africans with Haman and his ilk. The Book of Esther related directly to his social and religious experience, which he thought was similar to that of Esther and Mordecai. He saw God at work for justice in the history of Israel, although God's actions were veiled.

The members of his audience were set in extreme poverty with shacks for houses, no electricity or running water. They too were poorly educated. In their context the book of Esther was simply understood in terms of race: black versus white. Given the reading context, the blacks were associated with poverty and the whites with wealth. Because of their wealth, the latter were regarded as enjoying the favour of God. It is for this reason that the student saw that blacks desire to liberate themselves, whereas whites will defend their wealth and their favoured position as the "elected" race.

He realised very well that God might not in future be on the side of the blacks, but at least he was behind them in their struggle for liberation. The fact that the Jews had refrained from plundering their enemies served as an indication that the hard-won democratic rights in South Africa should not be used to destroy others.

What struck me in this meditation was the ease with which black, oppressed citizens were identified with the oppression of the Jews, and the wealthy, powerful white citizens with the abuse of power by Haman. An identification of this nature is very powerful, as it clearly indicates who possesses the moral high ground. Add to this the value of the religious text within Christianity. If one can argue in ultimate terms, and suggest religious legitimation, such a designation receives ultimate significance.

In both readings, I felt that one is either good or damned. There is no peace for the wicked! If a reader identifies with a biblical character, the biblical figure can give him or her a grip on how to handle life. This does not suggest that one should do what the character did, but one can use the character to illustrate a certain kind of behaviour. This interpretation expresses a kind of wish that should not be taken literally. In this sense, the revenge visited upon Haman and the subsequent identification of him with white support for apartheid can be interpreted as a wish for retribution of some sort, without expressing this in so many words.

I was disturbed, but I probably got what I deserved. Yet a few things were imprinted on my mind. Firstly, we had just moved from a racist regime to a non-racial social order, yet here I encounter familiar ethnic stereotypes. Secondly, I had that distinct feeling that David must have had when Nathan told him that he himself was the sinful man! (2 Sam 12:7). I felt the same ambiguity many members of my peer group feel, as expressed by an SABC journalist, Chris Louw (2000), after the brother of the former State President FW de Klerk (Willem de Klerk 2000) said we should keep our heads down while the rest of the country forgives us our trespasses: "I am stained with gun oil, the sweat of the parade ground and the blood of black children ... What is left for me? I am too old to be completely innocent and too young to be absolutely guilty. I am too innocent to offer apologies. I am too old to wash my hands of everything". 
I was extremely perturbed by this kind of reading as well as by my reaction to it. I never realised that whiteness could be rendered problematical.

To Beal (1998) the Book of Esther becomes a site for rethinking questions about the categories of self and other in relation to religion, nationalism and the possibility of annihilation. These two readings brought me face to face with identity and annihilation. On the one hand, I feel myself being marked and consigned, "othered" to oblivion. On the other hand, I am forced to see a self that has been suppressed by the public transcript of colonial privilege.

My entry point is found in the notions of public and hidden transcript as developed by James Scott in his book Domination and the arts of resistance. Hidden transcripts (1990). Having established what one can expect to be a public transcript, I will briefly describe my experience of the current South African public transcript. Three aspects will be discussed: accusations of racism, the process of reconciliation and the problematisation of whiteness. I will then proceed to look into some aspects of identity in the book of Esther before moving on to the problem of reading the Bible with the perpetrator.

\section{James Scott and public / hidden transcripts}

The public transcript is used as a description of the open interaction between subordinates and those who keep them in submission (1990:2). It is public, as it can be observed by anyone, and it is a transcript in the sense that it comprises not only what is said, but also what is done with the body during this open interaction. In other words, it seems quite comparable to a role one plays according to a particular script. For subordinates, that script is more or less written for them by those who dominate. A recent example is the execution of Timothy McVeigh. CNN.com published what they called a "Protocol for execution". It is a 54-page document setting up step-by-step procedures for execution (cf. Clark 2001). After the execution, the prison warden proclaimed that he had cooperated throughout the entire process. Similarly, the reaction from the media representatives after the execution was tapered to the question whether McVeigh had indeed played his role as the one being executed. All in all, it was pronounced that the public transcript for execution was followed. Except for two instances where the public received a glimpse of the transcript still hidden in McVeigh's mind. Firstly, the public were given McVeigh's last statement, the poem Invictus where he proclaimed his own victory. Secondly, he received the last rites from a priest, but no one revealed what exactly was said. Although one knows there is something, it will remain hidden, unless, of course, the priest speaks out.

The playing out of one's role is not always done willingly, especially in case of a great disparity in power. In this case, the role played by the subordinate will be stereotyped and ritualistic, as Scott observed in a description of a parade in Laos in 1985 (1990:59). No one really came to see it, except those on the reviewing stand and those who marched by. Says Scott (1990:59):

The show is all actors and no audience. More accurately, the actors are the audience;

this is a ritual that the Laotian party-state organizes for itself. Its purpose, one assumes,

is to suggest to the participants that they are a legitimate part of a larger fraternity of

communist states with the control, discipline, purpose, and might which that implies.

This is in sharp contrast to the McVeigh spectacle, which became an international media event.

Domination does not come of its own. It needs constant work, and the public transcript is one way through which such domination can be symbolised in a demonstration of power 
(Scott 1990:45). Central to the public transcript appears to be the following:

(a) Visible and / or physical affirmation of the power of the dominating elite as that of being powerful in a hierarchical relationship (1990:46).

(b) Because the powerful control the public stage, they are at liberty to conceal or reveal whatever they think is in the interest of the image they project towards their subordinates (1990:50).

(c) When the powerful have no choice but to reveal a negative aspect, they will necessarily beautify it in such a manner that their self-portrait is not damaged. Scott (1990:52) calls this "euphemization".

(d) The powerful elite will take great pains to foster a picture of cohesion amongst themselves, and of consent by their subordinates. An apology by a subordinate who violated the norms of domination is a sign of public acceptance of the power of the ruling elite, and it serves as a repair to the public transcript (1990:57). It is the show of compliance that is more important than the contents of the apology itself.

However, although the wishes of members of the dominant party normally prevail, their desires never control the stage completely. Over against their publicly self-authored portrait is the reaction of those who have to accept their own subordination. Scott refers to this reaction as a hidden transcript in so far as it takes place offstage (1990:4), removed from the eyes of the dominating elite's instruments of power. The audience intended by the hidden transcript is different from that of the public transcript and the transcript is also produced under different constraints. It is here that one gauges the difference between what is publicly said and what is privately expressed. Scott (1990:25) sees the hidden transcript as the privileged site for non-hegemonic, contrapuntal, dissident, subversive discourse. By definition the hidden transcript comprises a [or: consists of a] discourse that is excluded from the public transcript.

The hidden transcript is an acting out in fantasy of the anger and the reciprocal aggression denied by the public transcript (1990:38): "The frustration, tension, and control, necessary in public give way to unbridled retaliation in a safer setting, where the accounts of reciprocity are, symbolically at least, finally balanced."

The hidden text is a substitute for an act of assertion in the face of power. The images of dancing Palestinians and Libyans after the attack on the World Trade Centre in New York on September 11 seem to be a manifestation of such an acting-out, in the form of Schadenfreude.

The hidden transcript is a social product which exists only in so far as it is practised, articulated, enacted and disseminated within offstage social spaces that could be in themselves an achievement of resistance (Scott 1990:119). The realities of power, however, force the voices which are being dominated to acquire various elementary disguises. Scott (1990:156) suggests that these include anonymity, gossip, rumour, grumbling and euphemisms. More elaborate forms (Scott 1990: 156-172) are found in oral culture as popular disguise, the trickster in folktales, symbolic inversion and, important for the current discussion, the carnival.

The carnival is the ritual location of uninhibited speech (Scott 1990:175) where the dominated can direct their social aggression at dominant power figures, as is the case during Purim. Since it is the only time that these figures' immunity from open criticism is lifted, the carnival is a place of undominated discourse, or as Scott defines it, a discourse without servility, false pretences, obsequiousness or etiquettes of circumlocution. It gives a privileged place to normally suppressed speech and aggression (Scott 1990:181). 


\section{The South African public transcript}

In terms of the South African public transcript, I want to focus on the first two aspects Scott mentioned, namely the visible and / or physical affirmation of power as well as the revelation and concealment of what is thought to be in the interests of the dominant elite.

\section{a. The race card}

One of the instruments with which the current regime asserts its power is the use of race as a trump card in order to win any argument when criticism can no longer be answered. The issue of race is no longer part of the official public transcript. Apartheid has been removed, but its ideological construct, racism, is still part and parcel of South African life. Racism deliberately divides society into groups on the basis of physical appearance. This division is then subsumed into a hierarchy that breeds animosities as well as a belief in the superiority and inferiority of the levels of the hierarchy.

In the aftermath of apartheid where one will hardly find anyone openly admitting that he or she supported apartheid, the label of racism is regarded as an ostracisation of one from society. No one wants to deal with a racist. In terms of a debate where the racism card is used, the card places the one who is using it higher in the hierarchy (cf. Snyman 2002d), as the other dialoguing partner is scapegoated and thus ranked with the lower level in a hierarchy defined in terms of morality. A person tagged as a racist loses any moral standing.

However, calling one a racist does not always mean that this person is one. For example, Charlene Smith, a journalist of the weekly newspaper Mail \& Guardian, who was raped and who made it her mission in life not to be silenced by this terrible ordeal, was publicly rebuked by President Thabo Mbeki (Mbeki 2000) for having claimed that rape is an endemic feature of African society. But she never mentioned the word African. She simply said that the rape epidemic in South Africa would not end until people understand a culture in which rape is endemic, and that the epidemic has become a prime means of transmitting the disease (HIV) to young women and children. She argued that the coincidence of sex and power structures that are based on gender makes it clear that the social injustices and HIV prevention are intertwined (Smith 2000). Mbeki used the race card to divert criticism of his belief that AIDS is not caused by HIV.

The Charlene Smith incident, as far as it was constructed through discourse, was a visible affirmation of power by President Thabo Mbeki. Mbeki also did not reveal everything Smith said. In fact, he concealed the fact that she did not even talk about black South Africans, but rather about South African culture in general, which comprises not only different African traditions, but a lot more. It appears he wanted to garner support for his arguments. Playing the race card, he knew he would receive much African support, thereby closing the ranks and ostracising dissidents.

\section{b. Problematisation of whiteness}

The Charlene Smith incident shows that the identity of whiteness is today no longer a condition (once assumed unproblematically by those of European descent) to be cherished. An African public transcript is rendering it problematical. In this manner the power of the now-liberated colonised can be manifested vis-à-vis the former colonisers, who are forced to shift from filiation or biological continuity to social affiliation, engaging the new meaningfulness attached to ethnic tags. The two readings of Esther I have just presented illustrate that ethnicity is agonistically used. The concept is employed in struggles of self-affirmation, and discarded when it is in one's interest to do so. People whose material conditions have not changed use racial identity as a platform from which a struggle for equality is staged (cf. Wicomb 2001:180). 
The demise of apartheid did not cause the demise of ethnic tags; however, the system's collapse requires a disaffiliation from whiteness which is bound up with privilege and economic power. Whereas in advanced societies whiteness as a category is masked, in communities where the material effects of institutionalised racism still linger, not everyone wishes to abandon the racial tag. Ethnicity still testifies to a vast contrast between people.

The two Esther readings successfully ripped off the mask of my whiteness. I think Randall Bailey, in an essay on a postcolonial critique of American reading strategies, illustrates how this kind of mask operates. According to him (1998:74) black people in the USA bear the marks of being read within the dominant culture in which they lived as blacks. In other words, the interpretation of the Bible by people of European descent was simply assumed to be the valid interpretation for all people, regardless of their own cultures. He sees this public transcript as operating in terms of race. Its dominance forced black people to simply adopt the interpretation and symbols of a reading that masks whiteness. Bailey says (1998:78): "[W]e have been trained to read the stories in ways that support the ways in which whites read them and interpret them, which can run counter to our own psychic, spiritual, physical and emotional well-being."

Bailey refers to the image of Jesus and the interpretation of the colour white in the Bible. Regarding our images of Jesus, he argues correctly that a Jesus with blond hair and blue eyes is a typical European presentation (1998:75). When used as a tool of evangelism, Jesus needed to look like the locality in which the painting or statue would be received. But such an image should not be seen as an accurate historical depiction. Bailey regards the trend of perceiving the historical Jesus with blond hair and blue eyes as a "white supremacist" attitude and 'Western'. Similarly, the constant interpretation of white as something good adds to this idolatry of whiteness, which eventually found its way into the churches' liturgical colours where the colour white symbolises Christmas and Easter, and black is used for Good Friday. He argues that the Bible uses white also in relation to a curse, such as leprosy.

Bailey's striving to affirm blackness leads him to look for textual evidence of blackness in the biblical text. He works on the assumption that whiteness in American culture is masked. My question is: why does one need colour in the biblical text to affirm oneself? The answer is probably to regain some power, or at least some dignity. However, the result is a process of "othering", where the modernistic binary oppositions which Bailey seeks to overcome are only reinforced with zest. I suspect that the moment one can put a label onto something, one can control it and be master over its use. The terms "white" and "black" are such labels. They serve no other purpose than to divide people who want to reconcile their different members with one another. These terms qualify and quantify people in terms of colour, yet they do not relate anything biological, genetic or historical. They are used arbitrarily in the language of power, which divides people, and one has no choice but to side with the group that fits one's physical appearance. One could add: the group which fits one's religious beliefs, if one takes the aftermath of 11 September into consideration. The three aeroplane disasters have the potential to divide the Muslim world from the Christian world. Are we not confronted with a fascist tendency that opposes self-identification (cf. Snyman 2001)?

The concept of race is without any redeeming social or scientific value. Whiteness, if I can use the words of Wicomb (2001:159), is no longer a nice word:

Whiteness does not collocate with the key words of our narrative of freedom and thus there is no potential for discursive appropriations or refiguration of its general field of meaning. As a construct, whiteness cannot be fully addressed; indeed, it appears to be only from within and bound up with the meaning of a specific ethnic group that a revision can emerge; in other words, it must literally be deconstructed. 
c. A process of deconstruction: reconciliation

I wonder how a Persian audience would have reacted to the Book of Esther if they had ever heard it? The Book of Esther would never have operated as part of their public transcript if it had been written during the Persian period. One writes differently when one knows the object of derision is going to read or hear the text or not, especially if he or she is in power! In a study on the formation of new social identities in South Africa, the sociologists Liebenberg and Zegeye suggest (2001:326) that a confrontation with the naked truth about a history of violence and the abuse of power is no simple experience. They suggest two reasons: (a) There is no easy way to relate these abuses to moral codes for future conduct, given South Africa's collective past experience and historical recollection; and (b) it is not easy to make sense of these things in a lasting way, without driving the general public into the arms of embitterment and alienation. It is not easy to reconcile the truth about the past with the consolidation of democracy, democratic transparency and the existing (imposed) social identities.

The easy way out for most of us would have been to close the book on apartheid and to start anew with an unblemished and sanitised version of the past (cf. Duvenage 1999). But one should remember that the former power can no longer dictate. The cumbersome and arduous way that was followed by our Truth and Reconciliation Commission tries to establish, à la Habermas (1989), a kind of remembrance or solidarity with those who suffered under apartheid. But there is a danger, as verbalised by a psychologist in Antjie Krog's prize winning book Country of my skull (1998:170), in a presentation of some of the stories heard by the TRC:

The more you empathize with the victim, the more you become the victim: you display the same kind of symptoms - helplessness, wordlessness, anxiety, desperation. But for some people it is so unbearable being a victim that they become a perpetrator instead. You get rid of the pain by putting it into someone else, you become violent and make someone else your victim.

Athalya Brenner (1995:79) makes a similar point about the Jews in the story of Esther:

Nobody is wholly evil in mirrorland, although the reds are ultimately inferior and losers, as preordained by the symbolism of "white". Similarly, no one is wholly evil (Haman) or good (Mordecai) in Esther, although Mordecai is "our", and thus superior. A nonsimplistic tale of mirrors excludes simplistic morality. Thus, an ideo-moralistic reading of Esther can be rejected in favour of a phenomenological or political reading. The winners are those whose side we are on, not necessarily saintly but our favourites. Thus read, Esther is not a morality tale. It can be read as a politico-philosophical guide to life and survival. What does it take, in a diaspora framework, to survive and succeed as a Jew? The answers given are not altogether comforting: you have to mutate into your former adversary, or nearly that.

This strategy is not comforting in view of my students' identification with Esther and Mordecai! Yet, looking back at "white" history after the South African War (or the AngloBoer War) from 1899-1902, this is exactly what happened during apartheid. Those iniquities visited upon women and children in the concentration camps set up under the scorched-earth policy of Lord Kitchener ended by being visited upon other people during 1960-1990 (cf. Pretorius 2001).

Hence the call for a new public transcript that will inculcate a culture of common humanity, tolerance, accommodation and coexistence, in other words, "a constant awareness of the dignity of the 'other"'(Liebenberg \& Zegeye 2001:328). It is a call for a 
new social identity that is open-ended and fluid, an identity that is constantly in the process of construction as the subject moves from one social context to another (cf. Zegeye 2001b:1). This is a move away from the notion of the natural, static and unchanging group imposed from above. But how does one transcend categories of black and white in the end? Are we not suffering under the legacy of colonialism, namely two different discourses that are exclusive of each other? This is John Comaroff's (2001) suggestion.

The colonisers tried to convert the indigenous inhabitants of the colonies into rightsbearing free individuals, but regarded them at the same time as members of a primordial, imperfect homo sapiens. They created a bipolar construction that inculcated within many Africans a double consciousness, defined by Comaroff (2001:63) as the uneasy coexistence of two counter-discourses of constitutional entitlement. To the newly-established African middle class and the orthodox Christian churches the liberal ethos of universal human rights, of free, autonomous citizenship and individual entitlement was appealing, as could be observed in the Freedom Charter of the ANC, whose leaders were primarily alumni of mission schools. The other discourse favoured collectivity or the corporate personality. Individual entitlement is subordinated to culturally defined identities. This discourse asserts group rights, ethnic sovereignty and primordial cultural connections.

The conflict arising from these two discourses nearly derailed the process leading to the demise of apartheid. In Rwanda it produced genocide. In Zimbabwe it currently yields ethnic cleansing. In Mbeki's public transcript the latter discourse seems to be favoured more and more.

I therefore have to bear the following in mind when reflecting on the two kinds of reading I have presented: Firstly, people who suffer socio-economically will use the race card in their struggle to gain a better deal. Secondly, as with colonialism, one should expect a double consciousness, one where identity is still imposed from above and another where people are encouraged to construct new identities. The former happens with affirmative action and black empowerment, the latter happens in sport, labour and business. But the two discourses exclude one another, for as long as an identity is imposed from above, a self-constructed identity is not recognised. Where there is no threat, new social identities are allowed and recognised. However, in the face of a threat, one falls back on old identities.

\section{Esther and identity}

Whereas Esther is feted for coming out, I would rather closet or hide myself. My basic instinct tells me not to yield to the new public transcript, willingly accepting the position of a subordinate in terms of race. Hiding, as one of the motifs in the book, has a certain playfulness to it. Beal argues (1998:2) that Esther reads in one sense like a comedy in that the heroine withholds her identity only to reveal it at a crucial moment in the story, by which action the world is turned upside down. He adds that, although the tone is playful, the game is deadly serious: "The winners end up with prestige, authority, big houses, and lots of jewellery; the losers end up dethroned, banished, disenfranchised, dead in a pile, or impaled on a stake. The risks in this game are indeed high, and they are invariably entangled in issues of ethnic and gender identity."

Of course, the Book of Esther finds its raison d'être in the Jewish carnival, called Purim. Its reversals, dialectical relationships and mirror images find reciprocity in revelry, aberrant behaviour and the suspension of normal propriety (cf. Polish 1999:101-103). It is a time of mockery, mimicry and ridicule of even of the most sacred elements of religious expression. Whereas stories usually ask from their audience a willing suspension of 
disbelief, the carnivalesque asks a suspension of belief. Being closely tied to Purim, the book is steeped in carnival and masquerade. Purim celebrates a bizarre, mixed-up series of events. These events do not seem to make sense, but in the end, they all work out. The book celebrates an ancient story of court intrigue, deception, mis-communication, drunken parties, assassination plots, a foolish king, a delinquent queen, villains, a strong hero and one beautiful heroine. The context in which the book lives is that of comedy and its excesses.

Take away the last-mentioned, and the book is full of inhumanity, intolerance, nonaccommodation and lack of coexistence. It is as if the book masks a dark side of human existence, even when there is sympathy for the cause of survival. The two student readings which were offered regarded the book as suggestive of conduct in a crisis. They are readings in a search for role models in terms of morality (cf. Beal 1998:40 ff). But Esther's identity and the motif of hiding that is crucial to the book are glossed over. Esther has to be Jewish and Persian at the same time. If she reveals her Jewish identity, she is vulnerable to Haman's project (cf. Beal 1998:119). But being a Persian queen is already a denial of her Jewish roots. This dilemma leaves her a victim whose rape is necessary for the survival of her people (Lerner 2001:11). Her role is to absorb the story's shocks and tensions, to bear physically, and be worn away by, the inherent political contradictions of Jewish survival in the Diaspora; her happiness and personal piety are expendable. She simply disappears from the scene in what Beal refers to as a "fairy-tale settlement" which leaves the reader with ambiguities regarding the power of the Jewish people after the reversal of their fortunes and the their assumption of political power.

Brenner says that in Esther survival means mutating into one's adversary. Beal (1998:116) argues that Haman's projection of Mordecai and the Jews is a projection of his own ambivalence and insecurities. He brands the Jews with evil, but his own project is evil. Haman cannot exist without the Jews or Mordecai. There is a doubleness between Mordecai and Haman, the one being the mirror of the other.

Polish (1999:90) refers to them as Doppelgängers. Mordecai's ascent precipitates Haman's descent. The one's joy is the other's misery. Haman drinks with the king and Mordecai fasts and mourns. Mordecai is despondent, Haman is exuberant. The mood of the one is exchanged for the mood of the other. Polish (1999:90) sees them as substituting for one another: Haman receives the signet ring early in the narrative, but at the end of the development of the plot Mordecai receives the signet ring in nearly the same kind of scene as the one with Haman earlier on. Here they actually exchange roles. What Haman hoped for is attained by Mordecai; what Haman hoped would happen with the Jews is visited upon the Persians.

This doubleness invites a reader to see a symmetrical structure in the Book of Esther, so that there is closure, balance, cancellation without residue (McBride 1991:213). However, there is a measure of asymmetry. Mordecai does not simply replace Haman, and matches the degree of his personal favour with the king. Mordecai achieves more: acceptance and wealth, and peace for all his seed (10:3). The Jews defend themselves, killing 75000 people and winning over a considerable number of gentiles to their religion. McBride (1991:214) asks where the balance is, in killing so many foes who had only "prepared" to assault one. Rather than a mere specious cancellation, something is left over in the chiastic exchange. He understands this excess in terms of fiduciary terms: the excess or remainder constitutes a gain in terms of interest. Moreover, the slaughtering of so many people can be seen as a talionic response (with interest) to Haman's ten thousand talents of silver promised eleven months earlier. 
However, the carnival requires an intoxication to such a degree that one cannot distinguish between Mordecai and Haman. They converge. Blackness and whiteness can only operate in contrast with one another. To be black or white, one needs white or black as a contrast. After all, this is the legacy of modernity. Modernity appeared when Europe affirmed itself as the centre of the world history. That self-definition took place in a dialectical relation with the non-European alterity (Dussel 1993:65). Europe could only do that by exploring, conquering and colonising an alterity that gave back its image to itself. Does Africa now need a Europe (or the West) in the very same way in order to identify herself (cf. Snyman 2002c)?

\section{The coming-out of a perpetrator}

Beal adds (1990:116): "Reading Esther can open windows onto the strategies and mechanisms for projecting visions of negativity, abjection, divergence, otherness (construed along the lines of ethnicity as well as gender), and in the process can expose ambivalences and insecurities in the ones running the projector."

One can expose my students' identification with the text as stemming from the same essentialist and objectivist frameworks that are the basis for racism and apartheid. There would definitely be a residue of the colonial framework and mind-set. But the historical context demands something else, namely the coming-out of the one operating the projector, his participation in the new public transcript.

Esther has a double identity, one for herself and one for her colonial master, the king. Haman and Mordecai are a double act, the one being the darker shade of the other. I myself have lost my innocence and am in search of the rehabilitation of my identity. Being branded a perpetrator on the basis of race, I cannot side with Esther, because she and Mordecai are also victims of what I stand accused of. The only space left is that of Haman, who acted wickedly.

How does one, who is branded as a perpetrator, read the text? There is nothing salvific about the story. I keep on thinking of being in the same boat as those German soldiers who fought for Nazi Germany, not because they subscribed to National Socialism, but because they were drafted and forced to go to the war front. And their offspring have no monument to commemorate them. Their only monuments are found in those who overturned the events and who were victims (cf. Snyman 1999).

In Germany after the war, in what has been called the Historikerstreit, historians provided a sanitised version of their history. It was observed as a repression and relativisation of potentially disruptive elements in the cultural tradition and historical experience (cf. Pensky 1999:354). Past cultural traditions were appropriated selectively and unreflectively. Nazism was reduced to prejudice and an outbreak of irrationalism (Eley 1988:174). The past, that provoked criticism and rejection, was morally neutralised.

The focus on whiteness prohibits the masking of the past. It forces one to inquire into the conditions that allowed a system such as apartheid to have flourished. Apartheid caused a break in civilisation in South Africa, so that one cannot continue with previously-held doctrines and methodological presuppositions. In an essay on the Holocaust and doing theology in the face of the perpetrator, Krondorfer (2000:95) makes a case for a difference in doing a Christian theology that emerges from the past of a perpetrator culture and a response coming from a community that was severely victimised. Any lack of difference would make the Holocaust a historical misfortune among others, whereas in reality it was an event that shook the foundations of theology in the land of the perpetrators. He says (2000:96) that obliterating or downplaying one's identity enable one to employ 
universalising language without rooting oneself in one's own historical context. In doing this, one removes oneself from being socially, morally or biographically implicated in a culture that continually struggles over coming to terms with the perpetration of a crime against humanity (cf. Krondorfer 2000:102).

As after Auschwitz, I would suggest in terms of Krondorfer that one could read the Bible as a perpetrator under the confrontational gaze of survivors and witnesses. The voices of the victims, survivors and witnesses are equal to the reader's own voice. The outcome of such a reading process is the discovery that what one hears could very well be incompatible with one's theological assumptions. It is a dangerous enterprise, and certainly unpopular amongst victims and perpetrators, or their descendants. Krondorfer says that one must strike a balance between recognising one's religio-cultural roots in a tradition that did not question the abuse of human rights, yet keep a critical distance from the mentality of apartheid.

It is not a question of becoming a good perpetrator; but to focus only on the victim, says Krondorfer (2000:103), raises hermeneutical dilemmas about textual choices and cultural perspectives which are at risk of being misappropriated and falsely identified with. This could lead to a triumphalism where the struggle against apartheid is uncritically appropriated as a symbol by the perpetrator as if it belongs to his or her own gallery of martyrs.

The problem is that the Christian story does not provide one with a model for looking at oneself as a perpetrator or descendant of perpetrators (2000:102). The Bible cannot, because more than half of its texts originated in conjunction with power. I am referring here to the Old Testament, which presents us with several ideological constructs of those who commissioned the texts. The modes of production were with those who had the means, economically as well as politically, namely a small and élite class in an agrarian society where scribal activities were limited to about one percent of the entire population (Davies 1992:19).

In other words, the text itself is very much an instrument in the hands of the powerful elite within Judaism with which a public transcript was written. Rainer Albertz's distinction between the levels of religiosity in Israel may be helpful here (1992:41-44). He distinguishes three levels: (a) the official level of religion, which pertains to the state of Israel and on whose level the ideological battles were fought; (b) the intermediate or local level, which is linked to the local sanctuary and which reflects the religious pluralism of ancient Israel; and (c) the level of personal piety, the family unit and the household, where family experience found its place. Of particular concern here is the official religion constituted by the various religious offices, functionaries and institutions. These groups were constantly in power struggles with each other, each reflecting their ideologies in their respective texts. What was once generally accepted may find itself in a later period seriously undermined by the addition of other texts or the reworking of particular texts. But I think the main point is that these texts are soaked in the exertion of power (cf. Snyman 2000).

Writing was laborious and expensive, so that only those with administrative capabilities could employ writing. They would have been the people in power, or at least people who controlled the community in terms of customs, policies and privileges. In their efforts to hold onto power as long as possible, the texts they commissioned could very well have functioned in some way or the other to legitimise their dominant position. The texts probably reflect their norms, values, ideologies and politics over against those who would have been subordinated in terms of these texts. 


\section{Conclusion}

As any text has its origins within the margins of power, it is logical that any ruling elites will find structural resonances on various levels between their dominant position and some of the stories about rulers in the biblical texts. A dominant ruling elite can with considerable ease incorporate the biblical text into its own public transcript. These texts deal with power. Moreover, successful power can lay claim to divine legitimation. Consequently, in our past it was easy to justify apartheid theologically. The ruling elite merely had to identify with the portrait of the "Ancient Israel" in the biblical texts - a selfportrait of those in whose midst these texts were planted and given life. That is why Afrikaner civil religion was so successful in its grip on the average believer. The political changes have sowed havoc in their midst, as they now have to put up with a theological system that has borne evil fruit.

The questions such believers have to ask relate to those questions which Western culture in South Africa needs to ask itself. Postcolonial criticism has put these questions on the table. Postcolonial criticism, with its vociferous and decisive stance in opposition to Western influence, seeks to create a discursive space between the former coloniser and the once-colonised in order to forge a new public transcript. Postcolonial criticism not only questions norms and values of the former coloniser, but it inquires into the continuing ramification of the former colonial or apartheid ideological structures.

One ramification deserving attention is that which the story of Esther illustrates, namely the possibility of mutating into one's former adversary, the oppressed becoming the oppressor. From the current public transcript in South Africa as suggested by Comaroff, and actually seen in Mbeki's defence of his AIDS / HIV stance, and related to my two students' reading of Esther, it appears as if the former colonial agenda of binary opposition in terms of race is still holding sway in public discourse. The only difference is that the formerly colonised people impose their representation of the European on Euro-Africans. Moreover, the issue of racism is used to gain the moral high ground and to silence criticism of any sort.

The presence of race in public discourse is the result of residues of the (essentialist or objectivist) framework of the predominant "Western" line of thought. This framework is still commonplace in current Bible reading practices, as illustrated by these two naive realist readings of the Book of Esther. Bible readers are bound to illustrate their compliance with the very framework they seek to overcome, a mutation into the very adversary they oppose!

Race has become an important double component of the public transcript in South Africa. On the one hand, in a positive way, race is used to force an equal distribution of resources and to make amends for past discrimination. On the other hand, in a negative way, race is used to silence critics of the ruling elite by portraying the former as racists. It is this negative use of race that constructs the South African public transcript at the moment and the construction of which can be observed in the Bible reading process at grassroots level. It is a transcript of superiority over those whose existence is moulded along Western cultural lines, those who cannot hide their presence in Africa and whose past has bred racism.

A feature of the postcolonial condition is complicity, the necessary result of mutating into one's adversary. Despite the inauguration of a new democratic political dispensation with new societal structures reflecting a non-racial society in 1994, reading still takes place according to one's racial disposition. Herein lies the paradox of complicity and the danger for a new democracy. Inasmuch as a negative difference between the "African" and the "Western" is inscribed in the current South African public transcript, one oppressive discourse is displaced by another. 


\section{BIBLIOGRAPHY}

Albertz, R 1992. Religionsgeschichte Israels in alttestamentlicher Zeit. Teil 1: von den Anfängen bis zum Ende der Königszeit. Göttingen: Vandenhoeck \& Rupprecht.

Bailey, RC 1998. The danger of ignoring one's own cultural bias in interpreting the text. In The Postcolonial Bible, ed. Sugirtharajah, RS, 66-90. Sheffield: Sheffield Academic Press.

Brenner, A 1995. Looking at Esther through the looking glass. In A feminist companion to Esther, Judith, and Susannah, ed. Brenner, A, 71-80. Sheffield: Sheffield Academic Press.

Clark, C 2001. Protocol for execution: "We are ready." CNN.com. http://www2.cnn.com/SPECIALS/2001/okc/stories/execution.explainer.html

Comaroff, J 2001. Reflections on the colonial state, in South Africa and elsewhere: factions, fragments, facts and fictions. In Social identities in the New South Africa. After apartheid. In Social identities South Africa Series, ed. Zegeye, A, 37-80. Cape Town: Kwela and SA History Online.

Davies, PR 1992. In search of "ancient Israel." Journal for the Study of the Old Testament Supplement Series, vol. 148. Sheffield: Sheffield Academic Press.

De Klerk, W 2000. Afrikaners. Kroes, kras, kordaat. Cape Town: Human \& Rousseau.

Dussel, E 1993. Eurocentrism and Modernity (Introduction to the Frankfurt lectures). Boundary 220 (3, 65-76).

Duvenage, P. 1999. The politics of memory and forgetting after Auschwitz and apartheid. Philosophy and Social Criticism 25 (3): 1-28.

Eley, G 1988. Viewpoint: Nazism, politics and public memory: Thoughts on the West German Historikerstreit 1986-1987. Past \& Present 121:171-208.

Habermas, J 1989. The new Conservatism. Trans. Nicholsen, SW. Cambridge: MIT Press.

Jauß, Hans-Robert 1982. Ästhetische Erfahrung und literarische Hermeneutik. Frankfurt am Main: Suhrkamp.

Krog, A 1998. Country of my skull. Johannesburg: Random House.

Krondorfer, B 2000. Of faith and faces: Biblical texts, Holocaust testimony and German's 'After Auschwitz' theology. In Strange Fire. Reading the Bible after the Holocaust, ed. Linafelt, T, 86-105. Sheffield: Sheffield Academic Press.

Lerner, BD 2001. No happy ending for Esther. The Jewish Bible Quarterly 29 (1):4-12.

Liebenberg, I and Zegeye, A 2001. The truth and Reconciliation commission in South Africa: tentative implications drawn from public perceptions and contemporary debates. In Social identities in the New South Africa. After apartheid. Volume one. In Social identities South Africa Series, ed. Zegeye A, 321-31. Cape Town: Kwela Books and SA History Online.

Louw, C 2000. Boetman is die bliksem in. Beeld (electronic version) http://news24.com/ Afrikaans/Beeld/Nuusagtergrond/AFR_378567_1194631_SEO.asp.

Mbeki, T 2000. AIDS. Mbeki versus Leon. Letter (1 July 2000) to Leon. Sunday Times, 9 July, 16.

McBride, WT 1991. Esther Passes: Chiasm, Lex Talio, and money in the Book of Esther. In Not in Heaven. Coherence and complexity in Biblical narrative, ed. Rosenblatt, JP and Sitterson, JC, 211-23. Indiana: Indiana University Press.

Pensky, M 1999. On the use and abuse of memory: Habermas, "anamnestic solidarity," and 
the Historikerstreit. Philosophy and Social Criticism 15:351-80.

Polish, DF 1999. Aspects of Esther: A phenomenological exploration of the Megillah of Esther and the origins of Purim. JSOT 85:85-106.

Pretorius, F (ed.) 2001. Verskroeide aarde. Cape Town: Tafelberg.

Scott, JC 1990. Domination and the arts of resistance: Hidden transcripts. London: Yale University Press.

Smith, C 2000. Don't blame me - fight the plague. Mail \& Guardian, 14 July, 30.

Snyman, GF 1999a. 'Will it happen again?' Reflections on reconciliation and structural contraception. Religion \& Theology 6 (3):379-410.

1999b. "Ilahle elinothuthu?" The lay reader and / or the critical reader - some remarks on Africanisation. Religion \& Theology 6 (2):140-67.

2000. "Texts are fundamentally facts of power, not of democratic exchange." In

Past, Present, Future. The Deuteronomistic history and the prophets. In Oud

Testamentische Studiën Volume XLIV, ed. De Moor, J and Van Rooy, H, 272-305. Leiden: Brill.

2001. 'Who am I?' Some thoughts on fabricating the body in postcolonial/post-apartheid South Africa. Alternation 8 (1):188-218.

2002a. Identification and the discourse of fundamentalism. Reflections on a reading of the Book of Esther. In Rhetorical criticism and the Bible: Essays from the 1998 Florence Conference, ed. Porter, S and Stamps, D, 160-208. Sheffield: Sheffield Academic Press.

2002b. Narrative rationality, morality and readers' identification. OTE 15(1): 179199.

2002c. Eurocentrism and Africentrism: What is Western / African research? In Research, identity and rationalism: Thinking about theological research in Africa., ed. Du Toit, CW, 1-28. Pretoria: Unisa.

2002d. The body, rhetoric and post colonial criticism. Religion \& Theology 9(1/2):63-87.

Wicomb, Z 2001. Five Afrikaner texts and the rehabilitation of whiteness. In Culture in the New South Africa. After apartheid. Volume two. In Social identities South Africa Series, ed. Kriger, V \& Zegeye, A. 159-81. Cape Town: Kwela and SA History Online.

Zegeye, A 2001a. Social identities in the New South Africa. After apartheid. Social identities South Africa Series, vol. I. Cape Town: Kwela Books and SA History Online.

2001b. Imposed ethnicity. In Social identities in the New South Africa. After apartheid. Volume one. In Social identities South Africa Series, ed. A Zegeye, 1-23. Cape Town: Kwela Books and SA History Online. 